J. Clin. Chem. Clin. Biochem.

Vol. 26, 1988, pp. 423-427

(C) 1988 Walter de Gruyter \& Co. Berlin - New York

\title{
Haemostasis Contact System and Fibrinolysis in Hereditary Angioedema (Cl-Inhibitor Deficiency)
}

\author{
By M. Cugno, L. Bergamaschini, L. Uziel, M. Cicardi, A. Agostoni \\ Clinica Medica V, Università di Milano, Italy
}

Annie F. H. Jie and C. Kluft

Gaubius Institute TNO, Leiden, The Netherlands

(Received August 10, 1987/March 7, 1988)

Summary: Factors of the classical complement pathway, the contact system and fibrinolysis were evaluated both with functional and immunochemical methods, in patients with inherited deficiency of C1-inhibitor. Evaluations were performed under basal conditions, during acute attacks and during prophylaxis with low doses of anabolic steroids. Patients in the basal state showed no significant abnormalities of any of the parameters that we investigated. During acute attacks a slightly reduced prekallikrein concentration was registered. During treatment with low doses of danazol and stanozolol, protein $C$ and plasminogen were found to be increased. Our data suggest that $\mathrm{C} 1$-inhibitor deficiency per se does not lead to a derangement of the fibrinolysis and coagulation contact system, and that the kinin system may be involved during acute attacks of angioedema.

\section{Introduction}

Patients with hereditary angioedema have recurrent episodes of non-inflammatory swelling involving subcutaneous tissues, the upper airway mucosa and gastrointestinal tract. Death may result from obstruction of the larynx.

The biochemical abnormality is the deficiency of the inhibitor of the first component of complement (C1inhibitor) which is inherited as an autosomal dominant trait (1). Eighty percent of the patients have the predominant form (type I) of the disease, with low antigenic and functional plasma concentrations of $\mathrm{C1}$ inhibitor, the remaining $15 \%$ having the variant form (type II) with low functional activity only (2). C1inhibitor inhibits not only the proteolytic activity of C1 but also several enzymes of the haemostasis contact phase and fibrinolysis (3). The clinical observations that potentially profibrinolytic stimuli such as emotional or physical stress may trigger attacks of angioedema (4), that antifibrinolytic agents ( $\varepsilon$-ami- nocaproic acid, tranexamic acid) are effective for prophylaxis in hereditary angioedema (5), that plasmin seems to be necessary for the release of permeability mediator in hereditary angioedema (6) and that the contact system may be activated during acute attacks (7) could indicate that fibrinolysis and the haemostasis contact phase may both be implicated in the pathogenesis of the disease. This intricate problem has been discussed by several investigators $(7-11)$ but there are no definitive data in the literature. In this study we investigated the possibility of changes in coagulation and fibrinolytic systems in hereditary angioedema patients under basal conditions, and during acute attacks, using an extensive number of immunological and biological tests. Moreover, in a group of hereditary angioedema patients under long-term treatment with low doses of $17-\alpha$-alkylated androgens we evaluated whether these drugs could influence the contact system or the fibrinolysis parameters. In fact, high doses of anabolic steroids modified the blood concentrations of various components of the coagulation and fibrinolytic systems $(12-15)$. 


\section{Patients and Methods}

Patients

Three groups of patients with type I hereditary angioedema were studied:

1) 17 asymptomatic patients ( 10 females and 7 males, age range $12-56)$ without any treatment for at least 2 months;

2) 4 untreated patients (all females, age range 27-52) during acute attacks, involving the abdomen in 2 patients, the rigth arm in 1 patient and the right arm and left leg in 1 patient (blood samples were taken from one to three hours after the beginning of the attack);

3) 10 patients ( 4 females and 6 males, age range 25-61) on long term therapy with minimal effective doses of stanozolol $2-3 \mathrm{mg} /$ day (6 patients) or danazol $100-200 \mathrm{mg} /$ day (4 patients) for periods ranging from 6 months to 4 years.

A reference group consisted of 12 healthy donors ( 6 females and 6 males, age range $20-34$ ).

\section{Samples}

All plasma samples were prepared by collecting nine volumes of whole blood through a $19 \mathrm{G}$ butterfly cannula into one volume of $38 \mathrm{~g} / \mathrm{l}$ trisodium citrate in plastic tubes, without stasis and discarding the first $2 \mathrm{ml}$ of blood. Blood samples were taken in the morning before $11 \mathrm{a} . \mathrm{m}$., after an overnight fast and a rest of $15 \mathrm{~min}$. Platelet-poor plasma was obtained by immediately centrifuging the blood at $4{ }^{\circ} \mathrm{C}$ at $2000 \mathrm{~g}$ for 30 min. Plasma was then aliquoted into plastic tubes, snap frozen in a mixture of solid carbon dioxide and methanol and stored at $-80^{\circ} \mathrm{C}$ until use.

\section{Functional assays}

- Factor XII coagulant activity was measured by a one stage bioassay based on the activated partial thromboplastin time with a plasma congenitally deficient in factor XII (16).

- Prekallikrein was determined by a spectrophotometric assay, with control tests ensuring optimal conversion of prekallikrein to kallikrein by the dextran sulphate method (17).

- Fibrinogen was determined by the method of Clauss (18).

- Plasminogen was assessed by the streptokinase-activation procedure with the chromogenic substrate S-2251 (Kabi-Vitrum) (19); we calculated the concentration of free plasminogen from the equilibrium:

Plasminogen $\cdot$ Histidine rich glycoprotein $\rightleftharpoons$ Plasminogen + Histidine rich glycoprotein (20).

- Tissue plasminogen activator activity in the euglobulin fraction of plasma was measured by an indirect spectrophotometric assay in the presence of cyanogen bromide fragments of fibrinogen (stimulator), plasminogen and synthetic plasmin substrate S 2251 (Kabi Vitrum) (21).

- Tissue plasminogen activator inhibition of plasma was determined by a modification of the tissue plasminogen activator assay, as described by Verheijen (22).

- Antithrombin III activity was measured by a chromogenic substrate technique, using the synthetic substrate S 2238 (Kabi Vitrum) after full activation with heparin according to the manufacturer's instructions.

- C1-inhibitor was assayed by measuring esterolytic activity towards the substrate, $\mathrm{N}$-acetyl- $L$-tyrosine ethyl ester monohydrate, according to Lachmann (23).

\section{Immunochemical assays}

- Factor XII, protein C and histidine-rich glycoprotein were measured by the electroimmunoassays according to Laurell (24), using monospecific antisera (antiserum against human Factor XII - Nordic, antiserum against protein C kindly provided by Dr. P. M. Mannucci, antiserum against human histidine-rich glycoprotein manufactured in our laboratory).

- High molecular weight kininogen, antithrombin II, C1inhibitor and C4 antigens in plasma were determined by radial immunodiffusion, as described by Mancini (25), using monospecific antisera (antiserum against light chain of human high molecular weight kininogen - Nordic; antisera against antithrombin III, C1-inhibitor, C4 Behringwerke AG).

\section{Statistics}

The results were expressed as means \pm standard deviation; the significance of differences between means was assessed by the two-tailed Student $\mathrm{t}$ test; when the distribution of data was not normal (tissue type plasminogen activator activity and inhibition) the non-parametric test of Wilcoxon was used.

\section{Results}

All results are summarized in tables 1,2 and 3.

\section{Untreated hereditary angioedema patients}

The mean level of C1-inhibitor was $31 \%$ of normal, based on functional activity, and $19 \%$ of normal, based on antigen concentration (tab. 1); C4 antigen level was $28 \%$ of normal. Functional levels of C1inhibitor correlate with the antigen level $(p<0.001)$. Both functional and immunochemical levels of C1inhibitor correlate with $\mathrm{C} 4$ antigen levels $(\mathrm{p}<0.001)$. Haemostatic and fibrinolytic parameters were in the normal range and did not differ from those of the reference group (tabs. 2 and 3).

\section{Hereditary angioedema patients during acute attacks}

Complement parameters were further decreased; in two patients zero levels of $\mathrm{C} 4$ were recorded.

A decreased plasma concentration of prekallikrein ( $p<0.05$ ) (tab. 2) was observed; no significant changes were shown in the other studied components. However, the levels of Factor XII and high molecular weight kininogen tended to be lower (tab. 2).

The apparent increase in tissue-plasminogen activator activity is due to the very high value of this parameter in only one among the four patients, and it is obviously not statistically significant (tab. 3). 
Tab. 1. Complement parameters in hereditary angioedema patients.

\begin{tabular}{lllll}
\hline & $\begin{array}{l}\text { Reference } \\
\text { group } \\
\mathrm{n}=12\end{array}$ & $\begin{array}{l}\text { Untreated } \\
\text { patients } \\
\mathbf{n}=17\end{array}$ & $\begin{array}{l}\text { Patients during } \\
\text { acute attacks } \\
\mathbf{n}=4\end{array}$ & $\begin{array}{l}\text { Treated } \\
\text { patients } \\
\mathbf{n}=10\end{array}$ \\
\hline C1-inhibitor antigen (\%) & $97 \pm 14$ & $19 \pm 7$ & $14 \pm 5$ & $28 \pm 11$ \\
C1-inhibitor activity (\%) & $99 \pm 17$ & $31 \pm 8$ & $20 \pm 5$ & $36 \pm 7$ \\
C4 antigen (\%) & $83 \pm 15$ & $28 \pm 17$ & $10 \pm 13$ & $44 \pm 23$ \\
\hline
\end{tabular}

Values are expressed as percentage of a pool of normal plasma.

Tab. 2. Coagulation parameters in hereditary angioedema patients.

\begin{tabular}{lcccc}
\hline & $\begin{array}{l}\text { Reference } \\
\text { group } \\
\mathrm{n}=12\end{array}$ & $\begin{array}{l}\text { Untreated } \\
\text { patients } \\
\mathrm{n}=17\end{array}$ & $\begin{array}{l}\text { Patients during } \\
\text { acute attacks } \\
\mathrm{n}=4\end{array}$ & $\begin{array}{l}\text { Treated } \\
\text { patients } \\
\mathrm{n}=10\end{array}$ \\
\hline Factor XII antigen (\%) & $106 \pm 19$ & $100 \pm 21$ & $99 \pm 11$ & $111 \pm 20$ \\
Factor XII activity (\%) & $114 \pm 18$ & $119 \pm 27$ & $96 \pm 12$ & $104 \pm 25$ \\
Prekallikrein (\%) & $97 \pm 18$ & $104 \pm 18$ & $81 \pm 16^{*}$ & $90 \pm 9$ \\
High molecular weight kininogen & $89 \pm 18$ & $81 \pm 14$ & $71 \pm 9$ & $79 \pm 12$ \\
antigen (\%) & $99 \pm 14$ & $104 \pm 18$ & $98 \pm 6$ & $120 \pm 19^{*}$ \\
Protein C antigen (\%) & $105 \pm 6$ & $116 \pm 7 * *$ & $111 \pm 4$ & $120 \pm 7$ \\
Antithrombin III activity (\%) & $104 \pm 11$ & $110 \pm 10^{* *}$ & $97 \pm 17$ & $110 \pm 9$ \\
Antithrombin III antigen (\%) & & & & 9 \\
\hline
\end{tabular}

Values are expressed as percentage of a pool of normal plasma.

$* \mathrm{p}<0.05$

** Only 10 out of 17 untreated hereditary angioedema patients were available for determination of antithrombin III.

Tab. 3. Fibrinolysis parameters in hereditary angioedema patients.

\begin{tabular}{|c|c|c|c|c|c|c|c|c|c|}
\hline \multirow[b]{2}{*}{ Plasminogen activity (\%) } & \multicolumn{2}{|l|}{$\begin{array}{l}\text { Reference } \\
\text { group } \\
\mathrm{n}=12\end{array}$} & \multicolumn{2}{|l|}{$\begin{array}{l}\text { Untreated } \\
\text { patients } \\
n=17\end{array}$} & \multicolumn{2}{|c|}{$\begin{array}{l}\text { Patients during } \\
\text { acute attacks } \\
n=4\end{array}$} & \multicolumn{3}{|c|}{$\begin{array}{l}\text { Treated } \\
\text { patients } \\
n=10\end{array}$} \\
\hline & 100 & \pm 19 & 103 & 18 & 109 & \pm 16 & 130 & \pm & $14^{*}$ \\
\hline $\begin{array}{l}\text { Histidine rich glycoprotein } \\
\text { antigen }(\%)\end{array}$ & 93 & \pm 20 & $109 \pm$ & 25 & 95 & \pm 35 & 102 & $\overline{ \pm}$ & 29 \\
\hline Free plasminogen $(\%)$ & 53 & \pm 18 & 48 & 9 & 59 & \pm 18 & 67 & \pm & $16^{*}$ \\
\hline $\begin{array}{l}\text { Tissue plasminogen activator } \\
\text { activity }(U / 1)\end{array}$ & 15 & \pm 19 & 29 & $52 * *$ & 54 & \pm 65 & 29 & \pm & 43 \\
\hline $\begin{array}{l}\text { Tissue plasminogen activator inhibition } \\
\left(10^{3} \mathrm{U} / \mathrm{l}\right)\end{array}$ & $1.27 \pm$ & 0.38 & $1.5 \pm$ & $0.43 * *$ & $1.71 \pm$ & $\pm \quad 1.10$ & 1.7 & \pm & 0.56 \\
\hline Fibrinogen activity (mg/l) & 2590 & \pm 610 & 2380 & 590 & 2740 & \pm 670 & 2670 & & 440 \\
\hline
\end{tabular}

$* \mathrm{p}<0.005$

** Only 11 out of 17 untreated hereditary angioedema patients were available for determination of tissue plasminogen activator activity and inhibition.

Hereditary angioedema patients on long term therapy with minimal effective doses of 17 a-alkylated androgen

At low doses of androgen a slight increase of antigen concentration of $\mathrm{C} 1$-inhibitor $(\mathrm{p}<0.025)$ was noticed, with no significant increase in either C1-inhibitor functional activity or in C4 antigen (tab. 1).

The therapy resulted in increased packed cell volume $(p<0.005)$, plasminogen $(p<0.005)$, free plasmin- ogen $(p<0.005)$ and protein $C(p<0.05)$; a tendency to increased antithrombin III functional levels was also noticed (tabs. 2 and 3).

From the regression analysis between coagulation or fibrinolytic parameters and C1-inhibitor and C4 levels, we observed that high molecular weight kininogen correlated with $\mathrm{C} 1$-inhibitor activity $(\mathrm{p}<0.01)$ and C1-inhibitor antigen $(p<0.05)$ in hereditary angioedema patients, but not in normal subjects. 


\section{Discussion}

Only patients with the predominant form of hereditary angioedema (type I) were studied to avoid the different and unspecific interactions between the dysmorphic $\mathrm{C} 1$-inhibitor protein and the various components of the studied systems (26).

With this study we demonstrated that the extrinsic fibrinolysis and the haemostasis contact phase are not affected in type I hereditary angioedema patients under basal conditions. These data contrast with the report by Cullmann of increased functional Factor XII (10), and the opposite finding by Nilsson of low functional Factor XII (9).

To support our result we must stress that we performed the assay for Factor XII on 17 patients both with functional and immunochemical methods, in order to avoid a functional misestimation due to an in vitro activation of the contact phase. We can conclude that despite the lack of such an important regulating protein as $\mathrm{C} 1$-inhibitor, other compensating factors succeed in preventing gross activation under basal conditions.

The nature of the pathogenetic plasma factors and the mediators of attacks are still controversial. A major question is whether the fibrinolytic or the kininkallikrein system plays a key role in attacks. In vitro experiments demonstrated that a major vasoactive peptide, first found in hereditary angioedema plasma during attacks (27), can be released probably from $\mathrm{C} 2$ when this protein is incubated together with $\mathrm{C} 4$, $\mathrm{C} 1$ and plasmin (11). The other hypothesis is that the activation of the kallikrein, first proposed by Lander-

\section{References}

1. Donaldson, V. H. \& Evans, R. R. (1963) Am. J. Med. 35, 37-44.

2. Frank, M. M., Gelfand, J. A. \& Atkinson, J. P. (1976) Ann. Intern. Med. 84, 580-593.

3. Schapira, M., De Agostini, A., Schifferli, J. A. \& Colman, R. W. (1985) Complement 2, 111-126.

4. Cicardi, M., Bergamaschini, L., Marasini, B., Boccassini, G., Tucci, A. \& Agostoni, A. (1982) Am. J. Med. Sci. 284, 2-9.

5. Agostoni, A., Marasini, B., Cicardi, M., Martignoni, G. C., Uziel, L. \& Pietrogrande, M. (1978) Allergy 33, $211-$ 216.

6. Donaldson, V. H. (1968) J. Exp. Med. 127, 411-429.

7. Schapira, M., Silver, L. D., Scott, C. F., Schmaier, A. H., Prograis, L. J., Curd, J. G. \& Colman, R. W. (1983) New Engl. J. Med. 308, 1050-1053.

8. Fields, T., Ghebrehiwet, B. \& Kaplan, A. P. (1983) J. Allergy Clin. Immunol. 72, 54-60.

9. Nilsson, T. \& Bäck, O. (1985) Thromb. Research 40, 817821.

10. Cullmann, W., Kövary, P. M., Muller, N. \& Dick, W. (1982) Clin. Exp. Immunol. 49, 618-622. mann (28) and supported by detection of active kallikrein in suction blister fluid of hereditary angioedema patients (29), is a critical factor in attacks.

We failed to demonstrate major ohanges in the fibrinolytic system of plasma from hereditary angioedema patients during attacks. We did, however, find a significant reduction of prekallikrein and to a lesser extent of Factor XII and high molecular weight kininogen. The balance between synthesis and catabolism can smooth variations in the plasma levels of each factor, although this trend, consistent with the data of Shapira (7), suggests an involvment of the kinin system. The significant correlation between high molecular weight kininogen and $\mathrm{C} 1$-inhibitor in patients with hereditary angioedema but not in normal human controls suggests that $\mathrm{C} 1$-inhibitor, when at low levels, becomes critical for the control of high molecular weight kininogen metabolism.

In the group of patients treated with low doses of anabolic steroids, only a rise in plasminogen concentrations (approx 30\%) and protein C (approx 20\%) were observed, and there was no effect on the fibrinolytic system. This seems to be in accord with the observation that both fibrinolysis inhibitors ( $\varepsilon$-aminocaproic acid, tranexamic acid) and profibrinolytic drugs (stanozolol, danazol) $(12,30,31)$ are effective in hereditary angioedema.

\section{Acknowledgement}

This work is partially supported by "Progetto Finalizzato Ingegneria Genetica e Basi Molecolari delle Malattie Ereditarie" of C. N. R., Rome, Contract No. 86.000.57.51.
11. Donaldson, V. H., Rosen, F. S. \& Bing, D. H. (1977) Trans. Assoc. Am. Physic. 90, 174-187.

12. Laurell, C. B. \& Rannevik, G. (1979) J. Clin. Endocrinol. Metab. 49, 719-725.

13. Kluft, C., Preston, F. E., Malia, R. G., Bertina, R. M., Wijngaards, G., Greaves, M., Verheijen, J. H. \& Dooijewaard, G. (1984) Thromb. Haemostas. 5l, 157-164.

14. Gonzales, R., Alberca, I., Sala, N. \& Vicente, V. (1985) Thromb. Haemostas. 53, 320-322.

15. Fiessinger, J. N. \& Aiach, M. (1980) Thromb. Haemostas. $42,183-185$.

16. Cugno, M. M., Chantarangkul, V., Tripodi A. \& Mạnnucci, P. M. (1985) Clin. Lab. Haemat. 7, 75-81.

17. Kluft, C. (1978) J. Lab. Clin. Med. 91, 83-95.

18. Clauss, A. (1957) Acta Haematol. 17, 237-244.

19. Friberger, P. \& Knös, M. (1979) Plasminogen determination in human plasma, In: "Chromogenic peptide substrate", (Scully, M. \& Kakkar, V. V., eds.) Edinburgh: Churchill Livingstone.

20. Kluft, C., Preston, F. E., Malia, R.' G., Bertina, R. M., Wijngaards, G., Greaves, M. \& Verheijen, J. H. (1984) Thromb. Haemostas. 51, 157-164. 
21. Verheijen, J. H., Mullaart, E., Chang, G. T. G., Kluft, C. \& Wijngaards, G. (1982) Thromb. Haemostas. 48, 266269.

22. Verheijen, J. H., Chang, G. T. G. \& Kluft, C. (1984) Thromb. Haemostas. 51, 392-395.

23. Lachmann, P. J., Hobart, M. J. \& Aston, W. P. (1973) Complement technology, In: "Handbook of experimental immunology" (Weir, D. M., ed.) Oxford: Blackwell.

24. Laurell, C. B. (1966) Quantitative estimation of proteins by electrophoresis in antibody-containing agarose gel, In: "Protides of the biological fluids", Vol. 14 (Peeters, H., ed.) Amsterdam: Elsevier.

25. Mancini, G., Carbonara, A. \& Heremans, J. F. (1965) Immunochemistry $2,235-240$.

26. Donaldson, V. H., Harrison, R. A., Rosen, F. S., Bing, D. H., Kindness, G., Canar, J., Wagner, C. J. \& Awad, S. (1985) J. Clin. Invest. 75, 124-132.
27. Donaldson, V. H., Ratnoff, O. D., Da Silva, W. D. \& Rosen, F. S. (1969) J. Clin. Invest. 48, 642-653.

28. Landerman, N. S., Webster, M. D., Becker, E. L. \& Ratcliffe, H. E. (1962) J. Allergy 33, 330-341.

29. Curd, J. G., Prograis, L. J. \& Cochranc, C. G. (1980) J. Exp. Med. 152, $742-747$.

30. Verheijen, J. H. H., Rijhen, D. C., Chang, G. T. G., Preston, F. E. \& Kluft, C. (1984) Thromb. Haemostas. 51, 396397.

31. Hambley, H., Richards, A., Davidson, J. F., Walker, I. D. \& MacEwan, H. P. (1985) Danazol-effects of fibrinolysis, In: "Progress in fibrinolysis VII" (Davidson, J. F., Donati, M. B. \& Coccheri, S., eds.) Edinburgh, London, Melbourne, New York: Churchill Livingstone.

Dr. Massimo M. Cugno

Clinica Medica V

Ospedale S. Paolo

Via di Rudini, 8

I-20142 Milano 

. 